\title{
Business Legal Liability for Consumer Rights Breaching the Apartment
}

\author{
Andi MuhammadRusdi*, Faisal Santiago** \\ *Student at Doctoral Program of Law, Universitas Borobudur, Jakarta Indonesia \\ **Universitas Borobudur, Faculty of Law, Jakarta Indonesia \\ ** E-Mail of The Corresponding Author: pattipawaeonda@gmail.com
}

\begin{abstract}
Housing has a strategic role in shaping the character and personality of the nation and as an effort to develop Indonesian people as a whole, self-identity, independent, and productive. Therefore, the state is responsible for ensuring the fulfillment of the right to housing in the form of decent and affordable housing. Liability is divided into two, namely mistakes and risks. Thus known as responsibility on the basis of errors (liability without based on fault) and liability without error (liability without fault), known as risk responsibility or absolute liability (strict liability) that can be done by consumers if the developer defaults before PPJB Efforts is done through deliberations to reach consensus. If the word consensus cannot be reached, then the consumer can sue through a general court or if taking the path outside the court, in general the path taken is through arbitration

Business actors or developers who violate these provisions are threatened with criminal sanctions for a maximum of 5 years or a maximum fine of Rp2 billion. The threat of sanctions is contained in Article 62 of the Consumer Protection Act. In addition, developers who fail to provide infrastructure, facilities and public utilities will be subject to criminal acts based on Law Number 1 of 2011 concerning Housing and Settlement Areas, Article 162 paragraph (1) with a maximum fine of Rp. 5 billion.
\end{abstract}

Keywords: Legal Responsibility, Business Actors, Apartment Consumers

DOI: $10.7176 / \mathrm{JLPG} / 99-14$

Publication date:July $31^{\text {st }} 2020$

\section{A. INTRODUCTION}

Article $28 \mathrm{H}$ paragraph (1) of the 1945 Constitution of the Republic of Indonesia states that "Every person has the right to live in a prosperous life and spirit, to live, and to have a good and healthy environment and to have health services. ${ }^{1}$ Housing has a strategic role in shaping the character and personality of the nation and as an effort to develop Indonesian people as a whole, self-identity, independent, and productive. Therefore, the state is responsible for ensuring the fulfillment of the right to housing in the form of decent and affordable housing. The law is always developing dynamically in society, which is certainly appropriate or a good law is a law that is in accordance with the reflection of the values that apply in society that aims to be the basis and maintain order, justice and welfare of the community. The law also serves to serve the community in this case regulating public order, keeping people's behavior in accordance with the rule of law, so that their interests are protected by law. If the development of society increases, it must also be followed by the development of law, so that the need for law in community and state life is in line with development. ${ }^{2}$

Development development in Indonesia also causes more and more problems in transactions, such as the problem of consumer protection in consuming goods and / services available in the community, including in ownership transactions. Apartments have now become an alternative as housing needs in almost all countries, especially in its big cities.

The need for adequate housing is a human problem throughout the world, not only in developing countries but also in developed countries. Housing development is an effort to meet one of the basic human needs, as well as to improve the quality of the environment, give direction to the growth of the region, expand employment and drive economic activity in improving and equitable distribution of people's welfare. ${ }^{3}$

Housing and settlements are basic human needs that are very influential in shaping the nation's personality. Housing and settlements can not only be seen as a means of necessity of life, but more than that it is a process of settling human beings in creating living arrangements for society and themselves in revealing identity. Apartments become an alternative as a place to live and can be obtained by transferring rights such as

\footnotetext{
${ }^{1}$ Indonesia, Undang-Undang Dasar Negara Republik Indonesia Tahun 1945, arcitle 28H

${ }^{2}$ Gunawan Widjaya dan Ahmad Yani, 2000, Hukum Tentang Perlindungan Konsumen, Jakarta, Gramedia Pustaka Utama, p. 8

${ }^{3}$ Arie. S. Hutagalung, 2002, Serba Aneka Tanah Dalam Kegiatan Ekonomi, Cet.1, Depok, Badan Penerbit Fakultas Hukum Universitas Indonesia, p. 17.
} 
trading, exchanging, renting, and grants. ${ }^{1}$ The sale and purchase of these apartments is done by ordering or indenting in advance which is then set forth in the form of a preliminary or purchase agreement which is better known as a Sales and Purchase Agreement (PPJB) as a guide to secure the interests of the parties. In other words, this agreement is used to obtain down payment from consumers to facilitate the construction of apartments. $^{2}$

According to the Quarterly Point of responsibility must have a basis, namely things that cause legal rights for someone to sue others at the same time in the form of things that give birth to other people's legal obligations to provide accountability. ${ }^{3}$ According to civil law, responsibility is divided into two, namely error and risk. Thus known as responsibility on the basis of errors (liability without based on fault) and liability without error (liability without fault), known as risk responsibility or absolute liability (strict liability). The principle of accountability on the basis of mistakes means that a person is responsible because he made a mistake that harms others. Instead the principle of risk responsibility is that the plaintiff's consumer is no longer required but the defendant's producer is directly responsible as a business risk. Based on the provisions of Article 30 of Law Number 8 of 1999 concerning Consumer Protection, it is known that the government acts as a protector of the community and also as a coach of business actors in improving the progress of the industry and the country's economy. ${ }^{4}$ In addition to the Government, business actors also have responsibilities. ${ }^{5}$ Claimed knowledge and awareness of business actors in choosing the container used to wrap food to be purchased by consumers. As explained earlier, the responsibility that is imposed on business actors is the responsibility based on mistakes and absolute responsibility. Liability can be borne by the business actor if the business actor makes mistakes that are detrimental to others. While the absolute responsibility of the business actor is directly responsible for the risk of his business.

Law Number 20 Year 2011 Article 105 concerning Flats is that: ${ }^{6}$

1) Settlement of disputes in the field of flats is first sought based on deliberations for consensus.

2) In the case of dispute resolution through deliberation to reach consensus, the aggrieved party may sue through courts within the general court or outside the court based on choices agreed by the parties to the dispute through alternative dispute resolution.

3) Settlement of disputes outside the court as referred to in paragraph (2) is carried out through arbitration, consultation, negotiation, mediation, conciliation, and / or expert judgment in accordance with statutory provisions.

4) Settlement of disputes outside the court referred to in paragraph (3) does not eliminate criminal liability.

Thus, legal protection for consumers if the developer defaults before the Binding Agreement of Sale and Purchase (PPJB) can be done through deliberations for consensus. If the word consensus cannot be reached, then the consumer can sue through the general court or if taking the path outside the court, in general the path taken is through arbitration. If the consumer sues through a public court, then based on the provisions of Article 1338 paragraph (1) BW, every agreement that has been legally made is valid as a law for those who made it. So even though PPJB has not yet been made, Confirmation of Purchase Orders for apartments made between

\footnotetext{
${ }^{1}$ Arie S. Hutagalung, 2007, Kondominium dan Permasalahannya, Cet.1, Depok, Badan Penerbit Fakultas Hukum Universitas Indonesia, p.1.

${ }^{2}$ Subekti, 1996, Hukum Perjanjian, Jakarta, Intermasa, p. 79-80.

${ }^{3}$ Titik Triwulan dan Shinta Febrian, 2010, Perlindungan Hukum Bagi Pasien, Jakarta, Prestasi Pusaka, p. 48.

${ }^{4}$ Jhon Pieris dan Wiwik Sri Widiarty, 2007, Negara Hukum dan Perlindungan Konsumen, Jakarta, Pelangi Cendekia, p. 19.

${ }^{5}$ Indonesia, Law of the Republic of Indonesia Number 8 of 1999 concerning Consumer Protection, Article 30 states that "paragraph (1) Supervision of the implementation of consumer protection and the application of the provisions of the legislation is carried out by the government, the community, and non-governmental consumer protection institutions; paragraph (2) Oversight by the government as referred to in paragraph (1) shall be carried out by the Minister and / or the relevant technical minister; paragraph (3) Supervision by the public and nongovernmental consumer protection institutions is carried out on goods and / or services circulating in the market; Paragraph (4) If the results of the supervision referred to in paragraph (3) turn out to be deviating from the applicable laws and regulations and endanger consumers, the Minister and / or technical minister take action in accordance with the applicable laws and regulations; (5) Results of supervision conducted by the community and non-governmental consumer protection institutions can be disseminated to the public and can be conveyed to the Minister and technical ministers; Paragraph (6) Provisions for the implementation of supervisory duties as referred to in paragraph (1), paragraph (2) and paragraph (3) shall be stipulated by a Government Regulation.

${ }^{6}$ Indonesia, Undang-Undang Republik Indonesia Nomor 20 Tahun 2011 tentang Rumah Susun, Arcitle 105
} 
developers and consumers have been binding on both parties. Each party is obliged to implement the contents of the agreement.

Article 4 of Law Number 8 of 1999 concerning Consumer Protection states that consumer rights are: ${ }^{1}$

1. The right to comfort, security and safety in consuming goods and / or services;

2. The right to choose goods and / or services and obtain said goods and / or services in accordance with the exchange rate and conditions and guarantees promised

3. The right to correct, clear and honest information about the conditions and guarantees of goods and/ or services;

4. The right to be heard opinions and complaints on goods and / or services used;

5. The right to obtain advocacy, protection and efforts to resolve consumer protection disputes appropriately;

6. The right to consumer guidance and education;

7. The right to be treated or served properly and honestly and not discriminatory;

8. The right to receive compensation, compensation and / or compensation, if the goods and / or services received do not comply with the agreement or are not as intended;

9. Rights regulated in other statutory provisions.

From the above background, the formulation of the problem that will be examined in this paper is How is the Legal Responsibility of Business Actors for Violating Consumer Rights in Apartments?

\section{B. RESEARCH METHOD}

The problem approach used in this paper is to use a normative juridical approach, namely library law research and because this research is conducted by having library material. In this research a descriptiveanalytical type of research will be used with the reason that the results obtained from the literature study are then analyzed and discussed using a systematic discussion flow. Thus the results of the analysis and discussion are then described to facilitate drawing conclusions and making suggestions

\section{RESULTS AND DISCUSSION}

1. Legal Protection for Consumers in the event of a Default Manager Before PPJB

Article 1 number 3 of Act Number 8 of 1999 concerning Consumer Protection Business actors are every individual or business entity, both in the form of legal entity or non-legal entity established and domiciled or carrying out activities within the jurisdiction of the Republic of Indonesia, both alone and together through an agreement organizing business activities in various economic fields. Understanding of consumer protection for business actors based on Article 1 number 3 of the Consumer Protection Act, developers can be included in the category of business actors according to this understanding. Article 5 paragraph (1) Regulation of the Minister of Home Affairs Number 5 of 1974 concerning Provisions Regarding the Provision and Provision of Land for the Purposes of the Company states that "In implementing policies regarding the provision and provision of land according to this Regulation, what is meant by" Housing Development Company "is a company that engages in the construction of housing of various types in large numbers, on an area of land that will constitute a unitary residential environment, which is equipped with environmental infrastructure and social facilities needed by the people who inhabit it. Thus Business actors have the rights and obligations as stated in Law Number 8 of 1999 concerning Consumer Protection. ${ }^{2}$

Talking about responsibility, it cannot be separated from the principles of a responsibility, because the principle of responsibility is a very important matter in consumer protection. ${ }^{3}$

In general, the principles of responsibility in law can be distinguished, namely:

1. The principle of responsibility based on mistakes (liability based on fault), namely the principle which states that a person can only be held accountable legally if there is an element of error he did;

2. The principle of presumption to always be responsible (Presumption of liability), namely the principle which states the defendant is always considered responsible until he can prove, that he is innocent, so the burden of proof lies with the defendant;

3. The principle of presumption of non-responsibility (Presumption of nonliability), this principle is the opposite of the principle of presumption to always be responsible, where the defendant is always considered irresponsible until proven, that he is guilty;

\footnotetext{
${ }^{1}$ Indonesia, Undang-Undang Republik Indonesia Nomor 8 Tahun 1999 tentang Perlindungan Konsumen,
} Arcitle 4

${ }^{2}$ Shidarta, 2006, Hukum Perlindungan Konsumen Indonesia, Jakarta, Grasindo, p.58.

${ }^{3}$ Ibid, p. 73 
4. The principle of absolute liability (Strict liability), in this principle fixing mistakes is not a determining factor, but there are exceptions that make it possible to be released from responsibility, such as force majeure circumstances;

5. The principle of liability with limitations (limitation of liability), with the existence of this principle of responsibility, businesses must not unilaterally determine clauses that are detrimental to consumers, including limiting their maximum responsibilities. If there are restrictions, then they must be based on applicable laws.

The responsibility of business actors for consumer losses in the Consumer Protection Act is specifically regulated in Chapter VI, starting from Article 19 to Article 28. Based on Article 19 paragraph (1) of the Consumer Protection Act, it can be seen that the responsibilities of business actors include: ${ }^{1}$

1. Liability for compensation for damages;

2. Liability for compensation for pollution;

3. Liability for compensation for consumer losses.

The existence of defective goods and / or service products is not the only basis for the liability of business actors. This means that the responsibility of the business actor includes all losses suffered by consumers. In general, claims for compensation experienced by consumers as a result of using the product, whether in the form of material, physical or mental compensation, can be based on a number of the conditions mentioned, which outline are only two categories, namely compensation claims based on defaults and claim for compensation based on unlawful acts. ${ }^{2}$

Basically, consumer rights are the principle of reciprocity with the obligations of the business actor, this is directly dealing with the obligations of the business actor. However, it appears that the rights granted to consumers are more than the rights of business actors. Basically the consumer has 3 (three) interests as follows:

1. Physical interests, the intended physical interests of consumers are the interests of consumer bodies related to the security and safety of the body and / or soul in consuming goods and / or services. In every acquisition of goods and / services, these goods and / or services must meet the needs of life of the consumer and provide benefits for him. The physical interests of consumers can be disrupted if the acquisition of goods and / or services actually causes harm in the form of bodily health disorders or threats to the safety of their lives;

2. Socio-economic interests, socio-economic interests of consumers require that each consumer can obtain optimal results from the use of their economic resources in obtaining goods and / or services for their living needs. For this purpose the consumer must obtain correct and responsible information about the product. Consumers must also obtain relevant education to be able to understand consumer product information provided, the availability of effective compensation efforts if they are harmed in transactions and freedom to form organizations or groups that are included in decision making;

3. The interests of consumer protection, even though in various laws and regulations as if regulating and / or protecting consumers, but in reality their use contains certain obstacles that make it difficult for consumers. $^{3}$

The Consumer Protection Act tries to provide protection to the three consumer interests mentioned above. Nevertheless in the field implementation, consumers have not maximally obtained fair legal protection. In connection with the sale and purchase of apartments between developers and consumers, the developer's responsibility can be seen since the issuance of apartment offer brochures by developers, the implementation of an agreement to buy and sell apartments between developers and consumers until after the surrender of apartments from developers to consumers. Brochures issued by developers can also be used as a basis for a lawsuit for consumers who feel disadvantaged because there are no facilities as promised in the brochure. ${ }^{4}$

Legal Protection for consumers if the developer of the default can be seen from various aspects, that is according to the Civil Code which regulates in general the sanctions for a default, also according to the Consumer Protection Act, Article 6 and Article 7 regulates the rights and obligations of business actors and according to Article 16, acts that are prohibited for business actors not to fulfill orders and / or agreements on completion times as promised and do not fulfill promises for a service and / or achievement.

The provisions regarding dispute resolution are regulated in Article 45, as follows:

${ }^{1}$ Ahmadi Miru dan Sutarman Yodo, 2000, Hukum Perlindungan Konsumen, Jakarta, Raja Grafindo, p.125.

${ }^{2}$ Ibid, p. 127

${ }^{3}$ A. Z. Nasution, 1995, Konsumen dan Hukum, Tinjauan sosial Ekonomi dan Hukum pada Perlindungan Konsumen Indonesia, Jakarta, Pustaka Sinar Harapan, p. 78-80.

${ }^{4}$ Yusuf Sofie, 2009, Perlindungan Konsumen dan Instrumen-Instrumen Hukumnya, Bandung, Citra Aditia, p 114-115. 
1. Every disadvantaged consumer can sue the business actor through an institution tasked with resolving disputes between consumers and business actors or through the courts within the general court environment;

2. Settlement of consumer disputes can be reached through the court or outside the court based on the voluntary choice of the parties to the dispute;

3. Settlement of disputes outside the court referred to in paragraph (2) does not eliminate criminal liability as regulated in the Act;

4. If an attempt to settle a consumer dispute is resolved outside the court, a claim through the court can only be taken if the attempt is declared unsuccessful by one of the parties or by the parties to the dispute.

Legal protection for apartment consumers is more specifically regulated in Law Number 20 of 2011 concerning Flats, namely Article 105 states:

1. Settlement of disputes in the field of apartment must be sought in advance based on deliberation to reach consensus;

2. In the event that the settlement of a dispute through deliberation to reach consensus is not reached, the injured party may sue through a court which is in the general court environment or outside the court based on the choices agreed by the parties to the dispute through alternative dispute resolution;

3. Settlement of disputes outside the court as referred to in paragraph (2) is carried out through arbitration, consultation, negotiation, mediation, conciliation, and / or expert judgment in accordance with statutory provisions;

4. Settlement of disputes outside the court referred to in paragraph (3) does not eliminate criminal liability.

Provisions in Article 106 of the Law on Flats, the lawsuit can be carried out by:

1) Individual;

2) Legal entity;

3) Society; and / or

4) Government or related institutions.

Legal protection for consumers if the developer defaults before the PPJB can be done through deliberations for consensus. If the word consensus cannot be reached, then the consumer can sue through the general court or when taking the path outside the court, in general the path taken is through mediation. If the consumer sues through a public court, then based on the provisions of Article 1338 paragraph (1) of the Civil Code, every agreement that has been legally made is valid as a law for those who make it. So even though PPJB has not been made, the Confirmation of Apartment Purchase Orders made between developers and consumers has been binding on both parties. Each party is obliged to implement the contents of the agreement. It's just that because the Confirmation of Booking for Apartment Purchases on the waarmerking is a deed under the hand, then the evidence in court later requires other evidence and witnesses to prove its truth.

In buying and selling apartments between developers and consumers, the developer's responsibility can be seen from the issuance of apartment offer brochures by developers, the implementation of an agreement to buy and sell apartments between developers and consumers until after the surrender of apartments from developers to consumers. Brochures issued by developers can also be used as a basis for a lawsuit for consumers who feel disadvantaged because there are no facilities as promised in the brochure. Efforts that can be done by consumers if the developer defaults before PPJB is done through deliberations to reach consensus. If the word consensus cannot be reached, then the consumer can sue through the general court or if taking the path outside the court, in general the path taken is through arbitration.

\section{Legal liability of business actors for violations of consumer rights}

Basically, the principle of business actor responsibility is regulated in Article 19 of Law No. 8 of 1999 concerning Protection of Consumer Protection, namely:

1. Business actors are responsible for providing compensation for damage, pollution, or loss of consumers due to consuming goods or services produced or traded.

2. Compensation as referred to in paragraph (1) can be in the form of refunds or replacement of goods or services of this equivalent type, or other health care or services of this type or equivalent, or health care or compensation in accordance with the provisions of the laws and regulations. valid invitation.

3. The compensation is carried out within 7 days after the transaction date.

4. The granting of compensation as referred to in paragraph (1) and paragraph (2) does not eliminate the possibility of a claim for error.

5. The provisions referred to in paragraph (1) and paragraph (2) do not apply if the business actor can prove that the error is the customer's fault. 
Related to the implementation of this absolute responsibility is very urgent with the high resistance from the producers, not having good intentions in doing business, and many events that show consumers are not protected to the maximum. Indonesia is a large market share, both for local and international producers. However, the rights of consumers in this place have not received maximum protection. For most producers, consumers are only a source of income and profits. They generally do not obey the laws and regulations regarding product safety, correct product manufacturing procedures, do not list complete product information, and do not comply with various types of consumer protection. It is also undeniable that the public wants certain products in relatively affordable prices, but this market demand should still be addressed responsibly by the producers. Incidents of violations or deviations as mentioned above rarely occur in European countries or in other developed countries, in addition to the presence of goodwill from producers, but also because of strict supervision and severe sanctions.

The government in the effort to protect consumers has an important role as an intermediary between the interests of business actors and the interests of consumers, so that each party can go hand in hand without harming each other. The government must be responsible for fostering and implementing consumer protection, to guarantee the acquisition of consumer and business actors' rights and the implementation of consumer and business actor obligations as stipulated in Article 29 and Article 30 of the Consumer Protection Act. The government in the effort to protect consumers has an important role as an intermediary between the interests of business actors and the interests of consumers, so that each party can go hand in hand without harming each other. The government must be responsible for fostering and implementing consumer protection, to guarantee the acquisition of consumer and business actors' rights and the implementation of consumer and business actor obligations as stipulated in Article 29 and Article 30 of the UUPK.

Consumer protection is based on benefits, fairness, balance, security and safety of consumers, as well as legal certainty as stipulated in the provisions of Article 2 of the Consumer Protection Act. ${ }^{1}$ Consumer protection is carried out as a joint venture based on 5 (five) relevant principles in national development, namely: 1) The principle of benefits is intended to mandate that all efforts in the implementation of consumer protection must provide maximum benefits for the interests of consumers and the business as a whole; 2) The principle of justice is intended so that the participation of all people can be realized to its full potential and provide opportunities for consumers and businesses to obtain their rights and carry out their obligations fairly; 3) The principle of balance is intended to provide a balance between the interests of consumers, business people, and the government in the material or spiritual sense; 4) The principle of consumer security and safety is intended to provide guarantees for security and safety to consumers in the use, use and utilization of goods and / or services that are consumed or used; 5) The principle of legal certainty is intended so that both businesses and consumers obey the law and obtain justice in the implementation of consumer protection, and the state guarantees legal certainty.

Consumer protection in the property sector in particular determines the liability of business actors with consumers who suffer losses because it is not in accordance with the promised expectations, so the facts surrounding the event that causes the loss are first qualified as an act against the law. This means that it can be shown that the business actor's actions are acts that violate the law, whether in the form of a violation of consumer rights, or the business actor commits an act contrary to his own legal obligations, violates decency, or has done something that is contrary to the appropriateness and community life. in running its business, especially propriety in terms of producing and marketing its products. Product liability is the legal responsibility of the person or legal entity that produces a product, (producer, manufacturer) and / or party who sells the product and / or the party that distributes the product, including herein those involved in the commercial chain regarding the preparation or distribution of a product, and also includes the entrepreneurs, agents, and workers of the business entity above. There is another definition of product liability; namely a legal conception which is essentially intended to provide protection to consumers by freeing consumers from the burden of proving that consumer losses arise due to errors in the production process and at the same time giving birth to the responsibility of producers to provide compensation. ${ }^{2}$ This absolute responsibility is also based on the fact that responsibility based on unlawful acts of wrongdoing occurs when there is a deviation by applying the principle of responsibility without error, and also there is a strong tendency in the developing legal history that for cases where there is no the party that can be blamed, then for the sake of the principles of social justice to determine the party that must bear the loss is to impose it on those who may have no fault. ${ }^{3}$ Courts have tended to determine to perpetrators who act in their own interests and expect benefits from these activities.

${ }^{1}$ Indonesia, Undang-Undang Republik Indonesia Nomor 8 Tahun 1999 tentang Perlindungan Konsumen, Arcitle 2

${ }^{2}$ Janus Sidabalok, 2014, Hukum Perlindungan Konsumen, Bandung, Citra Aditya Bakti, p. 89.

${ }^{3}$ Siahaan NHT, 2000, Perilndungan Konsumen dan Tanggung Jawab Produk, Jakarta, Panta Rei, p. 15. 
The claim of responsibility is based on the fact that there is a loss suffered by a party as a result of a relationship between consumers and business actors in the use, utilization and use by consumers of goods and / or services produced by business actors. Provisions related to business actor responsibilities in the Consumer Protection Act:

1. Business actors are responsible for providing compensation for damage, pollution and / or loss of consumers due to consuming goods and / or services produced or traded.

2. Compensation can be in the form of refunds or replacement of goods and / or services of a similar or equivalent value, or health care and / or compensation in accordance with the provisions of the applicable laws and regulations.

3. The compensation is given within 7 (seven) days after the transaction date.

4. The granting of compensation does not eliminate the possibility of criminal prosecution based on further evidence regarding the existence of an element of error.

5. Provisions do not apply if the business actor can prove that the error is the fault of the consumer.

In an apartment business, the handover process from the developer to the consumer is one of the stages of a series of processes that must be carried out. This step is a transfer of apartment ownership rights from the developer to the consumer. By law, both parties agree to accept without the element of coercion. In the process consumers should be able to see how much the responsibility of the developer. The consumer has the right to re-examine the final condition of the building submitted by the developer, and check the final condition of the apartment building using the check list method. Some large-scale apartment developers who are quite reputable have already carried out this procedure. They already have standard production procedures, starting from the upstream production stage (initial planning stage and sub-contractor procurement stage) to the downstream stage (implementation phase, supervision stage, and maintenance stage). If all procedures have been carried out according to standards, it means the consumer has bought an apartment from a good developer. However, this does not necessarily guarantee that cases will not result in consumer losses, because many of the consumers conduct checks only at a glance, not carefully and carefully, and only find out things that are not in accordance with quality standards. some time later.

The developer only showed good building specifications. Therefore, whether or not there is a final checking procedure on the part of the developer, consumers should still have to take the initiative to conduct their own checks carefully. This checking procedure is an opportunity that should be given to consumers as the responsibility of the developer regarding the final results of the products offered, whether it is in accordance with what was promised from the beginning and in accordance with what is stated in the promotional brochure. Producers as business actors certainly have the duty and obligation to participate in creating and maintaining a healthy business climate that supports the development of the national economy as a whole. Therefore, the producers are responsible for carrying out their duties and obligations, namely through the application of legal norms, propriety, and upholding the customs that prevail in the business community. Business ethics is one of the guidelines for every business actor. The principle of business is business, cannot be applied, but must be with an understanding of business principles for development. So, as far as possible, businesses must work hard to make their business contribute to the improvement of overall national development.

Against sanctions for developers who default or developers who in fact have violated a lot of the rights of housing / apartment consumers are criminal threats set by the Government for business actors or developers who violate agreed terms. Criminally, consumers can indeed report developers or developers on charges of violating Article 8 paragraph (1) letter f of Law Number 8 of 1999 concerning Consumer Protection. This article states that "Business actors are prohibited from producing and / or trading goods and / or services that are not in accordance with the promises stated in the label, label, statement, advertisement or promotion of the sale of said goods and / or services."

Business actors or developers who violate these provisions are threatened with criminal sanctions for a maximum of 5 years or a maximum fine of Rp2 billion. The threat of sanctions is contained in Article 62 of the Consumer Protection Act. In addition, developers who fail to provide infrastructure, facilities and public utilities will be subject to criminal acts based on Law Number 1 of 2011 concerning Housing and Settlement Areas, Article 162 paragraph (1) with a maximum fine of Rp. 5 billion.

Developers who intentionally hand over and / or withdraw funds in excess of $80 \%$ of buyers before meeting the requirements, may be subject to Article 155 of the Housing and Settlement Act Article 42 paragraph 2. The article mentions the preliminary sale and purchase agreement as referred to in paragraph (1) performed after fulfilling the following requirements: 1) Land ownership status; 2) What has been agreed; 3) Ownership of permission to build a main building; 4) Availability of infrastructure, facilities and public utilities; 5) Housing construction of at least $20 \%$ (twenty percent). If there is a violation, the developer is threatened by imprisonment for a maximum of 1 (one) year or a maximum fine of Rp. 1 billion. In addition to sanctions in the form of fines, developers can also be subjected to administrative sanctions as contained in Article 150 of the Housing Act. Sanctions range from written warnings, revocation of business licenses, and closure of locations. 
On another aspect, the Ministry of PUPR asks consumers to evaluate all the clauses made by the developer or manager, both the clause in the PPJB / AJB apartment and the clause in the management contract. Standard clauses are prohibited in Act Number 8 of 1999 concerning Consumer Protection. Referring to Law Number 8 of 1999 concerning Consumer Protection. Article 4 of the Consumer Protection Act states that consumers have the right to be heard their opinions and complaints. It also includes through media and social media. Law No. 8 of 1999 concerning Consumer Protection specifically regulates consumer problems and provides a platform for aspirations and advocacy to be carried out by consumers in the event of irresponsible actions taken by producers. Expectations of Law Number 8 of 1999 concerning Consumer Protection are clearly very large

Although it is not yet perfect, but the existence of this law is a step forward in order to create healthy business activities in Indonesia in general, in an effort to provide protection to consumers in particular. Kepmenpera No. 9 / KPTS / M / 1995 concerning Guidelines for Binding Buy and Sell House in number 1 regulates the obligations of business actors in the housing, property / developer sector, namely: 1) The seller is obliged to carry out the construction of apartment buildings according to the agreed time according to architectural drawings, floor plans and building technical specifications, which have been mutually agreed upon and signed by both parties and are attached, which form an inseparable part of the binding deed of the sale and purchase of the house; 2) The Seller is obliged to complete the construction of buildings and hand over land and apartment buildings on time as promised to the Buyer, except because of Force Majeure which is beyond the Seller 's ability, such as war natural disasters, strikes, riots, fire, flood and government regulations or policies in the field of Monetary; 3) The seller before making the sale and or binding the sale and purchase of an apartment is required to have; (a) Permit for approval in principle of project plan from the local Regional Government and location permit from the Regency / Municipality Land Office. Specifically for DKI Jakarta, a land designation and use permit (SIPPT) permit; (b) Certificate from the Regency / Municipality Land Office, that the Developer has obtained land for the construction of housing and settlements; (c) Building Construction Permit; 4) The seller must take care of the registration of the acquisition of rights to land and apartment buildings, immediately after the transfer of rights to land and houses or the sale and purchase of houses (land and buildings) before the PPAT; 5) If the Seller fails to deliver the Land and Building apartment on time as promised to the Buyer, is required to pay a late delivery fee of $2 \%$ (two percent) of the total price of the apartment for each day of delay; 6 ) If the Seller is found to have neglected his obligation to take care of the registration of the acquisition of rights to the apartment, then the Buyer has the right and is deemed to have been authorized to take care of and carry out actions relating to the registration of the acquisition of the right to the apartment to the competent authority.

\section{CLOSING}

1. Conclusions

Legal protection for apartment consumers in Indonesia, shows that Law No. 8 of 1999 concerning Consumer Protection has not played the role as expected when it was set, namely providing legal protection for apartment consumer rights. This can be seen that there are still many violations that occur related to the sale and purchase transaction of apartments, where the party who is most disadvantaged is the consumer of the apartment. Among them are the incompatibility of quality standards and technical specifications of the apartment, the absence of timeliness in the delivery of the apartment, also the unavailability of social and public facilities that meet the standards, unbalanced sale and purchase agreements, with restrictions on the liability of the developer/ developer.

\section{Suggestions}

May Regency / City and / or Regional Provincial Governments be advised to increase supervision of apartment binding purchase agreements as specified in Article 10 of Law Number 20 of 2011 concerning Flats which states that Apartment Supervision which includes monitoring, evaluation, and corrective actions in accordance with the provisions of the legislation is the authority of the Regency / City Government and / or the Provincial Government of the Special Capital Region of Jakarta. The most important thing is asking the Government to amend the UUPK, Article 52 letter c related to the supervisory function on the inclusion of standard clauses, it should not be on BPSK but on the Supervisory Agency for the Independent Standard Independent Clause of the property, or transferred the BPSK's tasks to BPKN.

\section{References}

A. Z. Nasution, 1995, Konsumen dan Hukum, Tinjauan sosial Ekonomi dan Hukum pada Perlindungan Konsumen Indonesia, Pustaka Sinar Harapan,Jakarta.

Ahmadi Miru dan Sutarman Yodo, 2000, Hukum Perlindungan Konsumen, Raja Grafindo, Jakarta.

Arie. S. Hutagalung, 2002, Serba Aneka Tanah Dalam Kegiatan Ekonomi, Cet.1, Badan Penerbit Fakultas Hukum Universitas Indonesia, Depok. 
-------, 2007, Kondominium dan Permasalahannya, Cet.1, Badan Penerbit Fakultas Hukum Universitas Indonesia, Depok.

Gunawan Widjaya dan Ahmad Yani, 2000, Hukum Tentang Perlindungan Konsumen, Gramedia Pustaka Utama, Jakarta.

Janus Sidabalok, 2014, Hukum Perlindungan Konsumen, Citra Aditya Bakti, Bandung.

Jhon Pieris dan Wiwik Sri Widiarty, 2007, Negara Hukum dan Perlindungan Konsumen, Pelangi Cendekia, Jakarta.

Shidarta, 2006, Hukum Perlindungan Konsumen Indonesia, Grasindo, Jakarta.

Siahaan NHT, 2000, Perilndungan Konsumen dan Tanggung Jawab Produk, Panta Rei,Jakarta.

Subekti, 1996, Hukum Perjanjian, Intermasa, Jakarta.

Titik Triwulan dan Shinta Febrian, 2010, Perlindungan Hukum Bagi Pasien, Prestasi Pusaka, Jakarta.

Yusuf Sofie, 2009, Perlindungan Konsumen dan Instrumen-Instrumen Hukumnya, Citra Aditia, Bandung.

\section{Peraturan Perundang-Undangan :}

Indonesia, Undang-Undang Dasar Negara Keatuan Republik Indonesia Tahun 1945

-------, Undang-Undang Republik Indonesia tentang Kitab Undang-Undang Hukum Perdata

--------, Undang-Undang Republik Indonesia Nomor 8 Tahun 1999 tentang Perlindungan Konsumen

--------, Undang-Undang Republik Indonesia Nomor 1 Tahun 2011 tentang Perumahan Dan Kawasan Permukiman

--------, Indonesia, Undang-Undang Republik Indonesia Nomor 20 Tahun 2011 tentang Rumah Susun

Keputusan Menteri Negara Perumahan Rakyat Nomor 9/KPTS/M/Tahun 1995 tentang Pedoman Pengikatan Jual Beli Rumah 